\title{
Small Farmers and Market Economy: A Case Study of Dagomba in Northern Ghana
}

\author{
Katsushige Nakasone ${ }^{1, *}$, Murari Suvedi ${ }^{2}$ \\ ${ }^{1}$ Faculty of International Agriculture and Food Studies, Tokyo University of Agriculture, Tokyo, Japan \\ ${ }^{2}$ College of Agriculture and Natural Resources, Michigan State University, East Lansing, USA \\ *Corresponding author: katsu10@nodai.ac.jp
}

\begin{abstract}
Ghana is characterized by obvious economic disparities between northern and southern Ghana. In this paper, we analyze these disparities and economic growth by examining the current farming structure with reference to land use patterns and farming practices and linkages with the market economy. Using data collected through household surveys from 2004 to 2015 in the Dagomba area, gathered from five compounds of 12 to 14 farmers each, the study concludes that the position of agriculture as a source of income in rural areas has declined rapidly, indicating a potential de-agrarianization in rural Ghana. Nonetheless, in northern Ghana, which is resource-poor, agriculture is still seen as an important income source. Because of the unfavorable position of agriculture in the Ghanaian context, outmigration is occurring from rural to urban areas, especially by male family members, resulting in significant change in household composition (more elderly household heads). Changes in family composition and decreased farm sizes have an important implication for food security and livelihoods of Ghanaian families. All these adversities suggest the need to craft farming systems that encourage increased food production through the introduction of new production technology and crop diversification.
\end{abstract}

Keywords: Northern Ghana, farming system, food security, longitudinal study

Cite This Article: Katsushige Nakasone, and Murari Suvedi, "Small Farmers and Market Economy: A Case Study of Dagomba in Northern Ghana.” Journal of Food Security, vol. 5, no. 4 (2017): 134-147. doi: 10.12691/jfs-5-4-4.

\section{Introduction}

The economy of the Republic of Ghana was sluggish during the 1970s but moved toward improvement since Jerry Rawlings' government in the 1981s. The Rawlings government aimed to positively restore the economy and accepted the structural adjustment policy (SAP) recommended by the World Bank and the International Monetary Fund (IMF) to promote economic liberalization. Agriculture is the main sector of Ghana's economy; it contributes about $23 \%$ to the national gross domestic product (GDP). The government raised cocoa producers' price to motivate farmers to increase production and secure revenue by reducing production costs. From the mid-1980s to the late 1990s, cocoa production increased, and farmers gained economic benefits, particularly in the southern part of Ghana [1]. The production environment in the northern part of Ghana is not suitable for cultivating export crops such as cocoa. Livelihoods there mainly depend on subsistence production [2]. Therefore, farmers in northern Ghana remain economically disadvantaged because of increased prices of daily necessities and low labor wages. These conditions resulted in poor agricultural growth and poor agricultural performance, which are also associated with a shrinking government budget [1]. Currently, in the southern part of Ghana, crops cultivation for export and domestic sales is carried out by utilizing the high potential of agricultural production. On the other hand, in northern
Ghana, food crops are mainly grown for self-consumption because of the poor cultivation conditions. Such dual production structures show an obvious economic disparity between northern and southern Ghana [2]. However, Nakasone [3] indicates that Ghanian society is changing in the northern part mainly because the market economy has advanced in this region and farmers are participating in it. Farmers who have earned their livelihoods by cultivating crops for self-consumption now need cash to purchase daily necessities. The number of immigrant farmers and non-agricultural activities have increased to increase income [4], and this has greatly affected the agricultural scale reduction of farmers and the aging of farmers in the northern part of Ghana. In this paper, we will analyze the economic growth and disparity between the northern and the southern parts of Ghana. We will further explore the current farming structure with reference to land use patterns and farming practices. Finally, we will examine the transformation of farming practices as a result of market economy penetration in the northern part of Ghana.

\section{Economic Growth and the Agriculture Sector}

The economic structure of Ghana still depends on the export of primary products formed in the colonial period during the 1950s. These primary products consist of agricultural products and mineral resources, which are very unstable contributors to the national economy. The 
export of gold and cocoa from 2005 to 2010 accounted for more than 65\%. In 2011, oil appeared as an export product, and the total export accounted for $65 \%$ to $75 \%$ [5]. Because the fluctuation of the international market prices of these products is intense, trade income and the whole national economy in Ghana remain unstable.

As a percentage of the GDP in Ghana, the agriculture sector fell from 30\% to less than 25\% from 2006 to 2015, while the industry sector increased from $20 \%$ to over $25 \%$ during the same period. It reached $28.4 \%$ in 2012. The service sector contributed about $50 \%$ in 2007 , and it is increasing (Figure 1). The increase in the industry sector is related to the fact that oil mining has become commercial and the construction sector remained stable. However, if we observe the ratio by sector from 2006 to 2010, crops in the agriculture sector were the largest, accounting for over $20 \%$ of GDP. After 2011, the value shows a decreasing trend of crops in the agriculture sector to $17.3 \%$ in 2015 , next to the subdivision of the trade, hotels and restaurants service sector. Besides cocoa, the agricultural sector is also important for securing food because most of the people use agricultural products for home consumption.

Moreover, about $42 \%$ of the total population engaged in agriculture, and about $49 \%$ of the rural population primarily depended on this sector for their livelihood in $2010[9,10]$. Though both of these values are below 50\%, the largest proportion of the working population is in agriculture; the service sector is the second largest, at $30 \%$. Therefore, because nearly half of the total population lives in rural areas and over $40 \%$ of the workers are engaged in the agricultural sector, it is clear that the agricultural sector is one of the most important sectors in Ghana.

Ghana started implementing the Economic Recovery Program (ERP) and reforming the national economy after introducing SAP in 1983. The ERP aimed to improve foreign exchange policy and fiscal policy, and agricultural policy for farmers to receive legitimate interests. After 1984, an average economic growth rate of about 5\% has been recorded for more than ten years. Considering only the value of this economic growth rate, one could conclude that the national economy was performing at a high level. However, repayment of a large debt was squeezing the domestic economy. Therefore, it was not possible to improve the economic structure, which depended on exports of primary products that had been in existence since before independence [3].

John Kufuor, who won the presidential election in 2001, decided to apply the Enhanced Heavily Indebted Poor Countries (HIPC) Initiative to improve the external debt problem that placed a heavy burden on the national finances. In 2004, the completion point of the Enhanced HIPC Initiative was reached, and it was decided to cancel debt totaling about $\$ 3.5$ billion [11]. The foreign policy of Ghana was to make a big change by the new government, but the domestic economic growth strategy continued in the direction of economic liberalization and the utilization of the private sector promoted by the former government. The concrete policy plan was created as the Ghana Poverty Reduction Strategy (GPRS), and a comprehensive development strategy was presented as a medium-term target. The GPRS I (2003) set targets focusing on promoting economic development and reducing poverty. In the GPRS II (2005), it was judged that the economy of Ghana was shifting from the stage of "restoration and reconstruction" to "accelerated growth", and along with promoting further economic growth, the plan set the goal of joining the middle-income countries by 2015 [12,13].

After the implementation of the growth strategy by GPRS, Ghana's economic growth rate increased dramatically -- by $14.1 \%$ in 2011 , but only $3.9 \%$ during 2015 (Figure 2). However, Ghana has continued to have a positive long-term GDP growth rate since the mid-1980s, and the state economy has remained relatively stable. The agriculture sector recorded negative growth in 2007 but recovered to show more than 7\% growth in 2008 and 2009. The growth rate from 2011 to 2015 varied from $0.9 \%$ to $5.7 \%$. Crops accounting for a large proportion of the GDP among agricultural sectors maintained relatively stable growth rates except in 2007 and 2012. Although the growth rate value is variable -- ranging from $2 \%$ to $10.2 \%$ -- it is expected that the agricultural sector will continue to maintain positive growth. Also, the industrial sector showed a growth rate of more than $40 \%$ in 2011 , due to the factory construction and capital investment related to the oil industry and oil becoming a new export product in Ghana during 2010-2011.

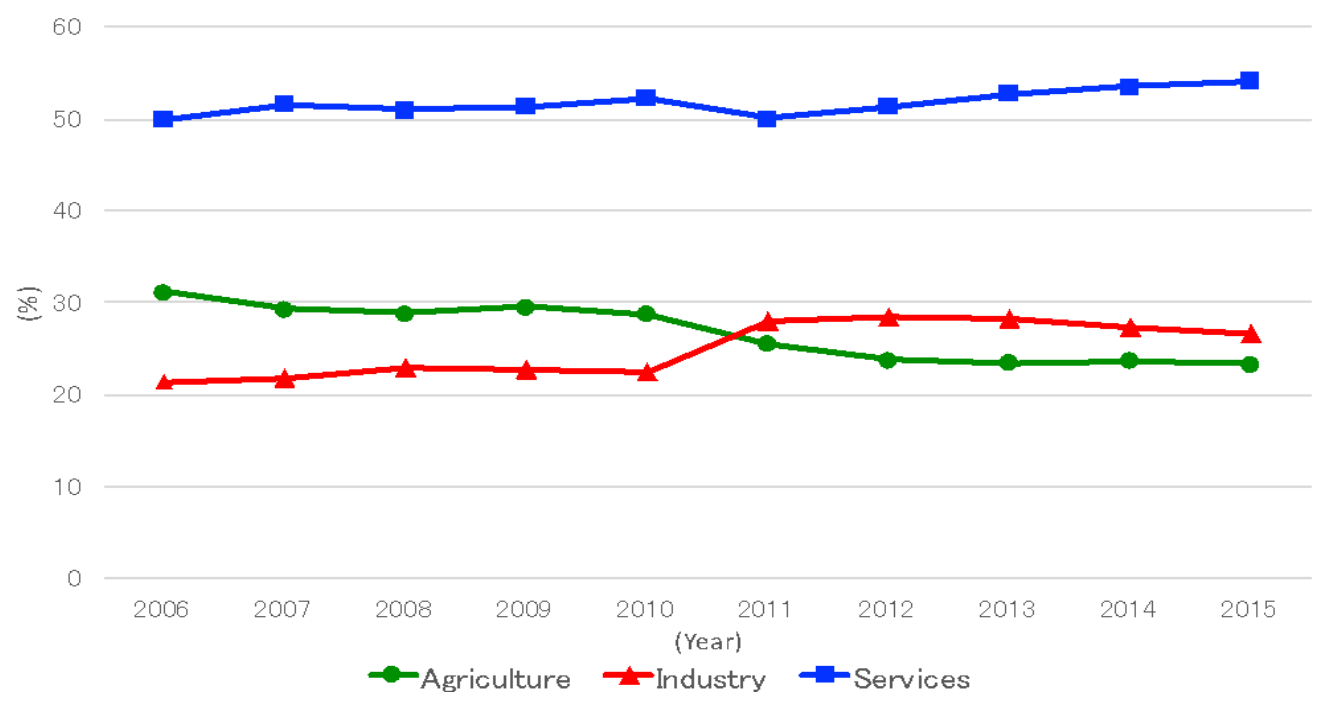

Figure 1. Percentage of GDP per sector in Ghana, 2006-2015 (Source: GSS, 2011, 2013, 2016.) 


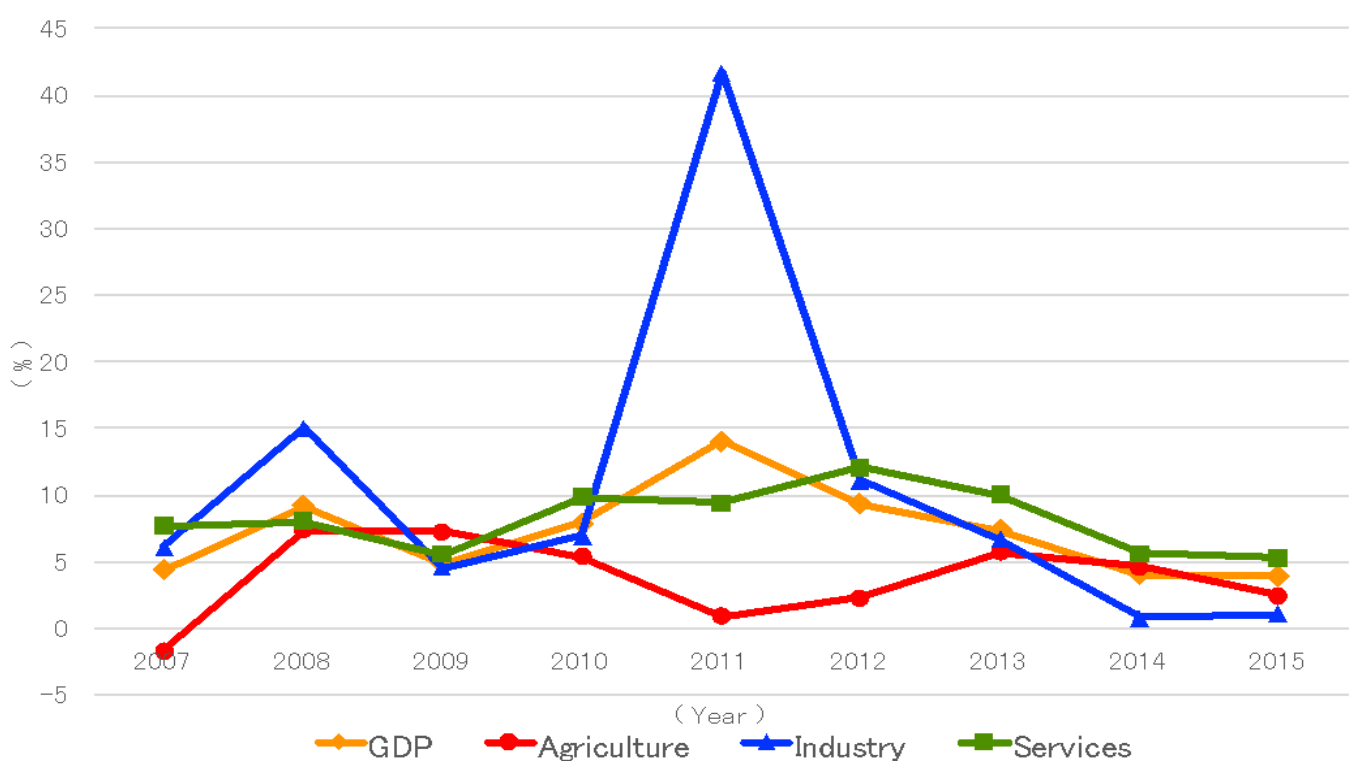

Figure 2. Growth ratio of GDP per sector, 2007-2015 (Source: GSS, 2011, 2013, 2016.)

\section{Domestic Regional Economic Disparity}

Since the 1980s, Ghana has maintained relatively stable growth while applying two different policies, SAP and the Enhanced HIPC Initiative. An economic liberalization policy in Ghana has also been advanced in the agriculture sector, together with mining as a major export sector. However, gold and cacao are traditionally exported products in Ghana that are mainly produced in the southern part of Ghana. Oil is a new and emerging export product produced along the coastal area in the southern part of Ghana. Meanwhile, agriculture is the only core sector in the northern part of Ghana, which does not have any mineral resources. The northern part of Ghana is in the savanna belt, and agriculture in that region is primarily rain-fed. Food crop production from this region is used mainly for domestic consumption. The lack of mineral resources and adverse climatic conditions for agriculture in northern Ghana mean that the region has long been devoid of strategies for economic growth. In recent years, the long-standing policy difference between the northern and southern parts has been recognized as one of the reasons for increasing economic disparities in Ghana $[3,10,14]$.

Figure 3 shows the income per capita by region in 1999 , 2006, and 2013. This data came from a large survey of domestic households conducted by the Ghana government. Targeted households were located in the greater Accra region and the Ashanti region in the south, where there are mineral resources and high agricultural production potential and, consequently, higher incomes. On the other hand, the incomes of the Northern, Upper West, and Upper East regions, which are called "the three northern regions", are very low and far below the average per capita national income. (The location of each regions is shown in Figure 6.)

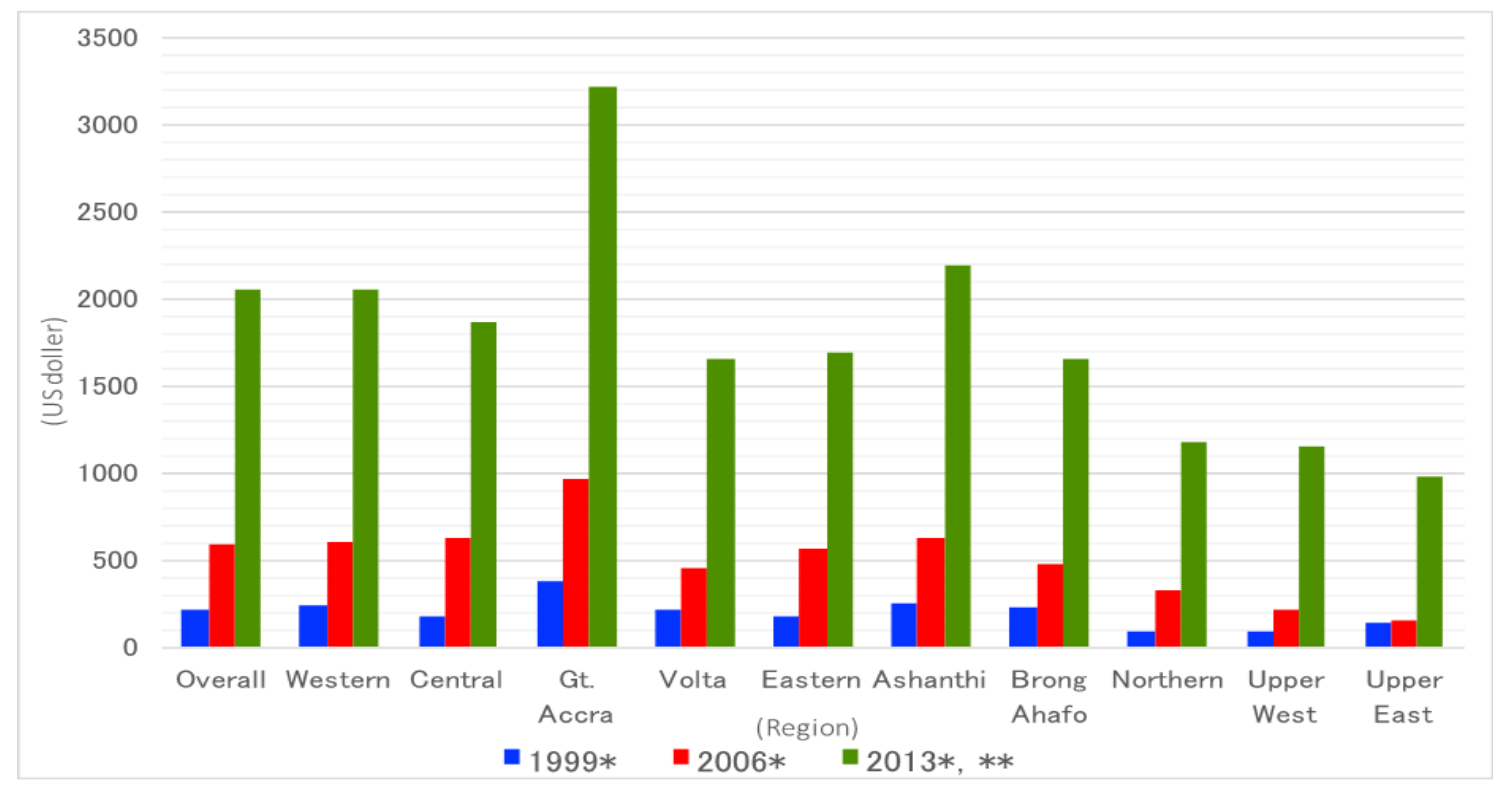

Figure 3. Per capita income by region in various years (Unit: US dollars) (Source: GSS, 2000, 2009, 2014b. [15,16,17]) $(*$ US\$1.00 = 2779.10 Cedi in 1999, US\$1.00 = 9179.80 Cedi in 2006, US\$1.00 = 0.66 GH Cedi in 2013: these exchange rates by Bank of Ghana [each year average], **Calculation of GDP by New System of National Accounts: SNA from 2010) 
Table 1 presents the income situation in urban and rural areas of Ghana in 1999, 2006, and 2013. The total household income and per capita income are higher in urban areas than in the rural areas. However, other urban areas had higher incomes than Accra in 2013. This fact is thought to be due to the rapid growth of Accra's population, high unemployment rate, and increased population of low-income people. In rural areas, household income and income per capita in the coastal area in 1999 were smaller than in the forest area. But income per capita in the coastal area was the highest of all of rural areas in 2006. This phenomenon appeared to be due to the fact that vegetable production for urban areas and fruit production for export were increasing in rural communities of coastal areas. In the savanna area, both income per capita and household income are the lowest among urban and rural areas in the country.

Figure 4 shows the pattern of changes in household income sources in rural areas during 1999, 2006, and 2013. In the coastal area, employment wage income had increased and the agricultural income proportion sharply decreased in 2013.

In the forest area, agricultural income accounted for more than 50\% during 1999 , which drastically declined to
$15 \%$ in 2013 . Wage employment increased from $15.6 \%$ to $43 \%$ in the same period. In the savanna area, which had the lowest income of all rural areas, more than $70 \%$ of income sources were agricultural income in 1999 and 2006. In this area, employment wage and other incomes rapidly increased in 2013, and the proportion of agricultural income declined to less than half that of 1999 and 2006. This change in the income sources in the savanna area is thought to be related to an increase in the number of farmers moving toward non-agricultural activities. This indicates that the liberalization of the economy has spread to rural areas. However, agricultural income in the savanna area accounted for $28 \%$ even in 2013, indicating that the income from agriculture may occupy an important position there compared with other rural areas. Overall, the changes in the proportions of income sources show that dependence on income from agriculture decreased in all areas from 2006 to 2013. Therefore, in rural areas of Ghana it is necessary to consider the agricultural structure and its problems with a view to the possibility that simple de-agrarianization is going to shift livelihood away from agriculture and toward non-agricultural activities expected to have high income [18].

Table 1. Change of income in urban and rural areas $(1999,2006$, and 2013)

\begin{tabular}{|c|c|c|c|c|c|c|c|c|c|c|}
\hline & & \multicolumn{3}{|c|}{$\begin{array}{l}\text { Household income } \\
\text { ( US dollars*) }\end{array}$} & \multicolumn{3}{|c|}{$\begin{array}{l}\text { Income per capita } \\
\text { ( US dollars*) }\end{array}$} & \multicolumn{3}{|c|}{$\begin{array}{c}\text { Percentage of GNI } \\
(\%)\end{array}$} \\
\hline & & 1999 & 2006 & $2013 * *$ & 1999 & 2006 & $2013 * *$ & 1999 & 2006 & 2013 \\
\hline \multirow[t]{3}{*}{ Urban } & Accra & 1,259 & 2,762 & 11,236 & 350 & 1,015 & 3,698 & 16.2 & 22.6 & 17.7 \\
\hline & Other urban areas & 856 & 1,992 & 15,000 & 214 & 714 & 5,063 & 27.4 & 32.6 & 51.4 \\
\hline & Total for urban & 972 & 2,248 & 13,814 & 249 & 814 & 4,633 & 43.7 & 55.2 & 69.2 \\
\hline \multirow[t]{4}{*}{ Rural } & Coastal & 581 & 1,461 & 7,492 & 142 & 525 & 2,430 & 11.0 & 10.1 & 4.1 \\
\hline & Forest & 847 & 1,495 & 7,988 & 188 & 464 & 2,519 & 31.7 & 23.3 & 18.6 \\
\hline & Savanna & 641 & 1,170 & 6,663 & 26 & 278 & 1,416 & 13.6 & 11.4 & 8.1 \\
\hline & Total for rural & 726 & 1,390 & 7,529 & 169 & 420 & 2,180 & 56.3 & 44.8 & 30.8 \\
\hline
\end{tabular}

(Source: GSS, 2000, 2009, 2014b, [15,16,17]) (*US\$1.00 = 2779.10 Cedi in 1999; US\$1.00 = 9179.80 Cedi in 2006; US\$1.00 = 0.66 GH Cedi in 2013; these exchange rates by Bank of Ghana [each year average], **Calculation of GDP by New System of National Accounts (SNA) from 2010.)

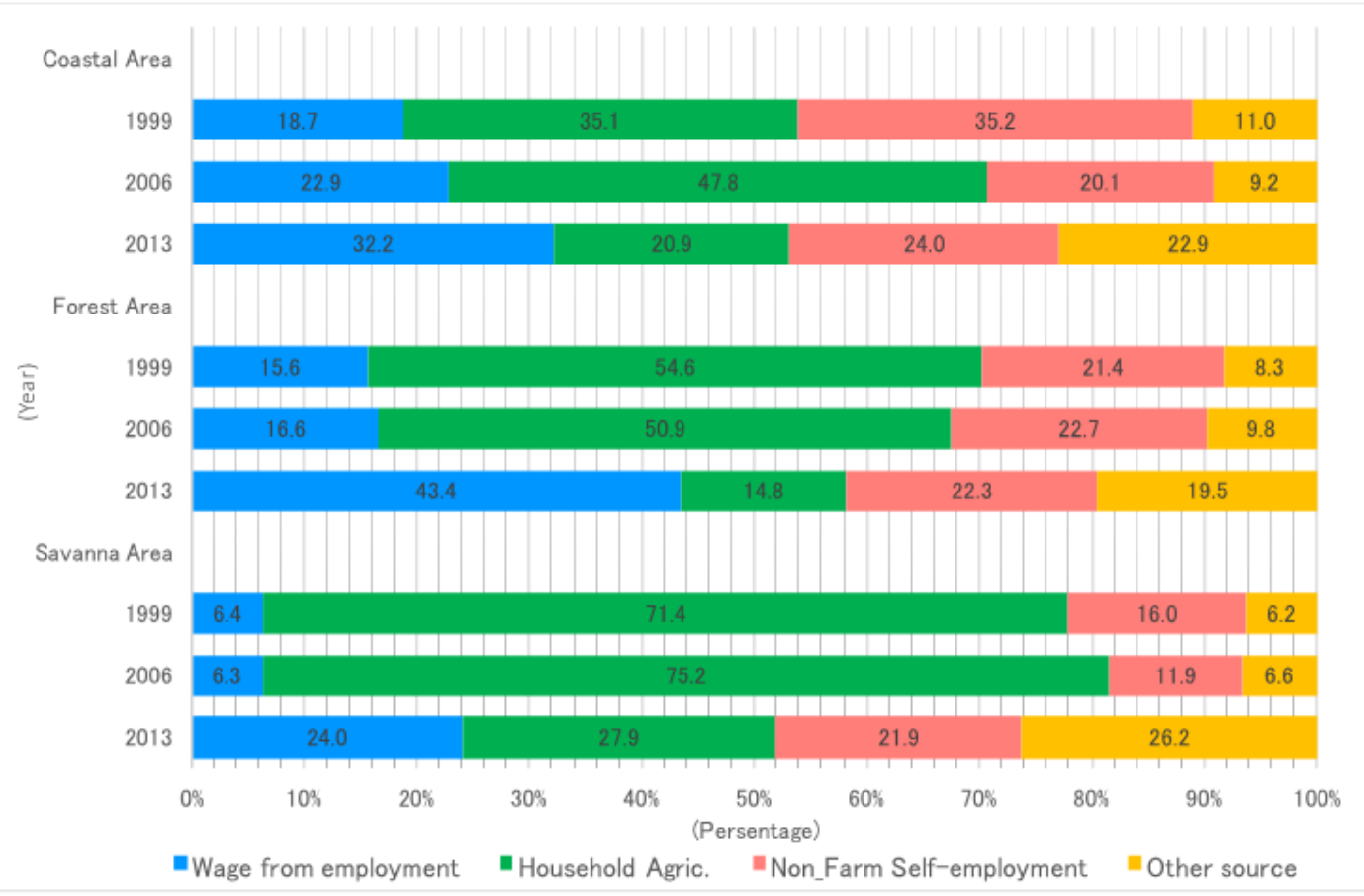

Figure 4. Changes in income sources in rural areas in 1999, 2006, and 2013 (Source: GSS, 2000, 2009, 2014b, [15,16,17]) 


\section{Farming System in Northern Ghana}

\subsection{Agriculture Overview in Dagomba Area}

Dagomba is the largest ethnic group in the northern part of Ghana. Among the Dagomba, farming is the primary occupation, with compound fields and bush fields. Compound fields lie in the vicinity of the compound, and productivity is high because of the soil, which often contains organic matter from livestock excreta and residues from the home. Since the 1990s, however, the size of compound fields per compound has been decreasing because of increased population [19]. Bush fields can be classified into "upland," where cereals, roots and tubers are grown, and "lowland," where rice is cultivated. Bush fields may be situated close to the compound or several kilometers away. The crops cultivated in bush fields are mostly used for domestic consumption by farmers and their families. The most commonly grown crops are roots and tubers, cereals, legumes, and vegetables. The root and tubers -- mainly yam and cassava-- are the important crops, but cultivation of yam is more labor-intensive than cassava. Cassava is gaining in popularity in the region because it incurs low cultivation cost, is easy to harvest and transport as a dry chip, and requires less labor input than yam [20]. Major cereals grown in the region are maize, millet, sorghum, and rice. Maize and sorghum, especially, used to be intercropped with legumes such as groundnut, but in recent years, intercropping has given way to growing cereals as mono-crops. Production of sorghum and millet has decreased because of their low productivity. Rice is a common crop that is cultivated in lowland fields mainly by young farmers. Additionally, various types of beans are cultivated, such as groundnut, cowpea, pigeon pea, bambara nut, and soybean, though groundnut is the primary one. Vegetables such as okra and red pepper are cultivated, but production of these crops is limited because they are used for home consumption [21].

The basic cropping system in this area is bush rotational fallow $[22,23,24]$. Bush rotational fallow is a cropping system that uses land by rotation of cultivation and fallow. Crop rotations of bush fields are determined by the condition of soil nutrients. Traditionally, crops were cultivated in certain fields for 4 to 5 years and were left fallow for 1 to 5 years. The crop cultivated at the beginning of the cycle was yam, followed by cereals and legumes intermixing or intercropping for 2 to 3 years, and in the fourth year cereals or legumes were cultivated as a mono-crop. The last crop of crop rotation was cassava because it has capacity to absorb soil nutrients even in poor soils. After that, land is kept fallow to rebuild soil nutrients. In recent years, however, the reduction of soil nutrients has been recognized as a major problem because land use is intensifying as field size decreases and population increases in this area [19].

Agricultural equipment in this area consists of conventional farming tools that depend on human power, such as hoe, cutlass (machete), knife, sickle, and stick. The hoe is a primary tool for plowing. Some farmers use tractors and bullocks for growing cereals using the ridge cultivation method. Sowing and weeding are done mainly by stick and hoe. Harvesting is done by hand or by using a knife, sickle, hoe, or cutlass. Men share labor for cultivating and weeding. Some farmers shorten the time needed for various tasks by using communal labor or hiring labor. Male farmers mainly harvest roots and tubers; males and females jointly harvest cereals and legumes $[21,25]$.

\subsection{Land Tenure System and Compound Farming}

According to Oppong [26], in Dagomba areas, a compound (called Yili) is the basis of life. The Dagomba are a paternal group, and each compound is basically composed of a family of one lineage. The household head (HHH) -- called Yili Yidana -- manages all of the life in general, including the economic activity of the compound.

In the land tenure system among the Dagomba, the land is divided from the head chief of the Dagomba (called $\mathrm{Ya}-\mathrm{Na}$ ) to the chief of each village. The village chief then allocates land to each compound in the village. The $\mathrm{HHH}$ in each compound redistributes the land to family members [21,26,27].

Basically, the HHH makes decisions on food security in the compound, but farming management of the compound is shared by HHHs and family members who have divided land from him. The selection of the crops to be cultivated is basically decided by individual farmers. The $\mathrm{HHH}$ (or eldest farmer) decides the amount of in-house consumption of harvested crops and stores that in a warehouse of the compound. The use of non-consumption crops by family members produced by each farmer is entrusted to the individual farmers, who manage the cash earned through crop sales. Therefore, their production activities have two objects: to provide a stable supply of food to family members in compound, and to produce crops to sell to earn income. Accordingly, in the Dagomba compounds, a multilayered farming structure exists (Figure 5), which consists of the two subjective aspects of community and individual, and two objectives of self-sufficiency and sales [2,21].

\subsection{Material of Survey}

The data for this study were obtained from annual field surveys conducted in the Dagomba region from 2005 to 2015. In the Tolon-Kumbung district of the northern region, the survey was conducted in two villages, Tingoli (hereafter noted as T) -- a small village -- and Gbullung (hereafter noted as G) -- a medium-scale village (Figure 6).

The village $\mathrm{T}$ is located about $20 \mathrm{~km}$ west of Tamale, the capital city of the northern region, and about $8 \mathrm{~km}$ from the main road connecting Tamale and Tolon (capital of the Tolon-Kumbung district). In this village, where more than 1,600 people live in about 100 compounds, there are few non-agricultural activities, and most of the adults are engaged in farming. Electricity can be used for light, but firewood and charcoal are used for cooking. The water for daily use is drawn from the ponds and rivers nearby the village. The village holds no regular market, so to buy seasonings and daily necessities for life, village people have to go to the nearest town, Tamale. There is also one public primary school in the village; nearly half of the children living in this village attend every day. 


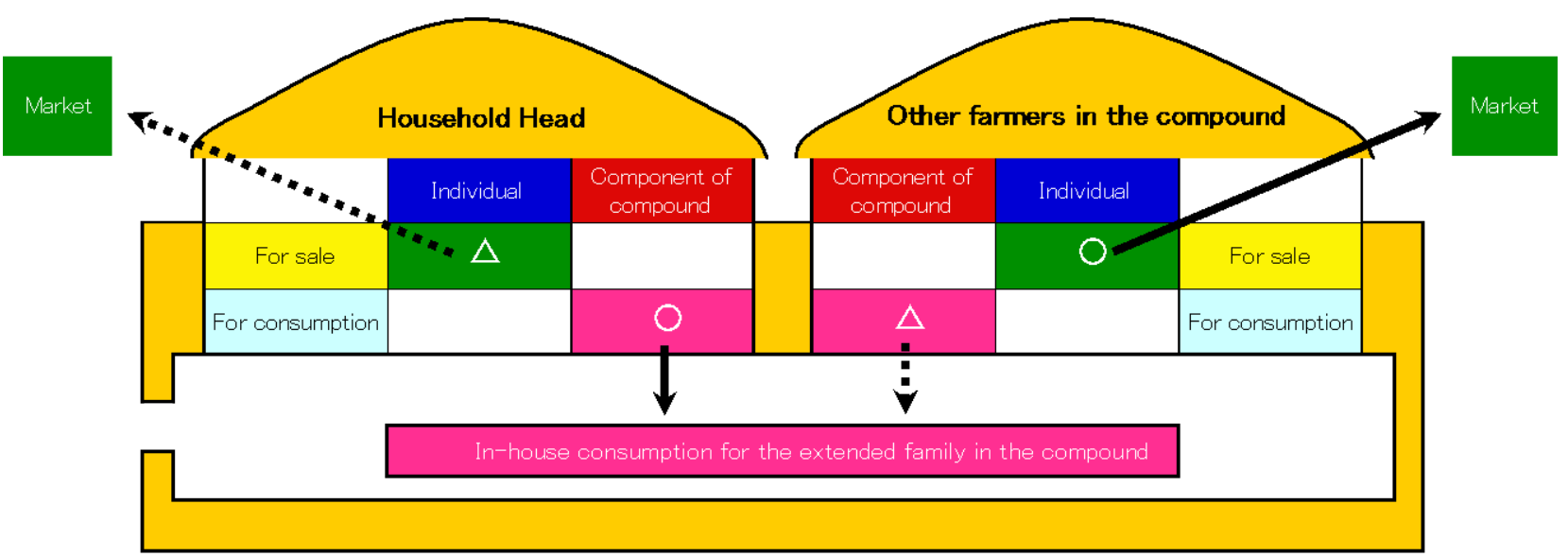

Figure 5. Relationship between agricultural production role and farming purpose in each farmer of compound. (Source: Nakasone, 2013b.) (Note: $\bigcirc$ and $\triangle$ indicate the strength of agricultural production and the direction of farming purpose for each farmer of the compound. Household heads have a high degree of importance to the food security for the compound; other farmers have a high degree of importance to the crop sales.)

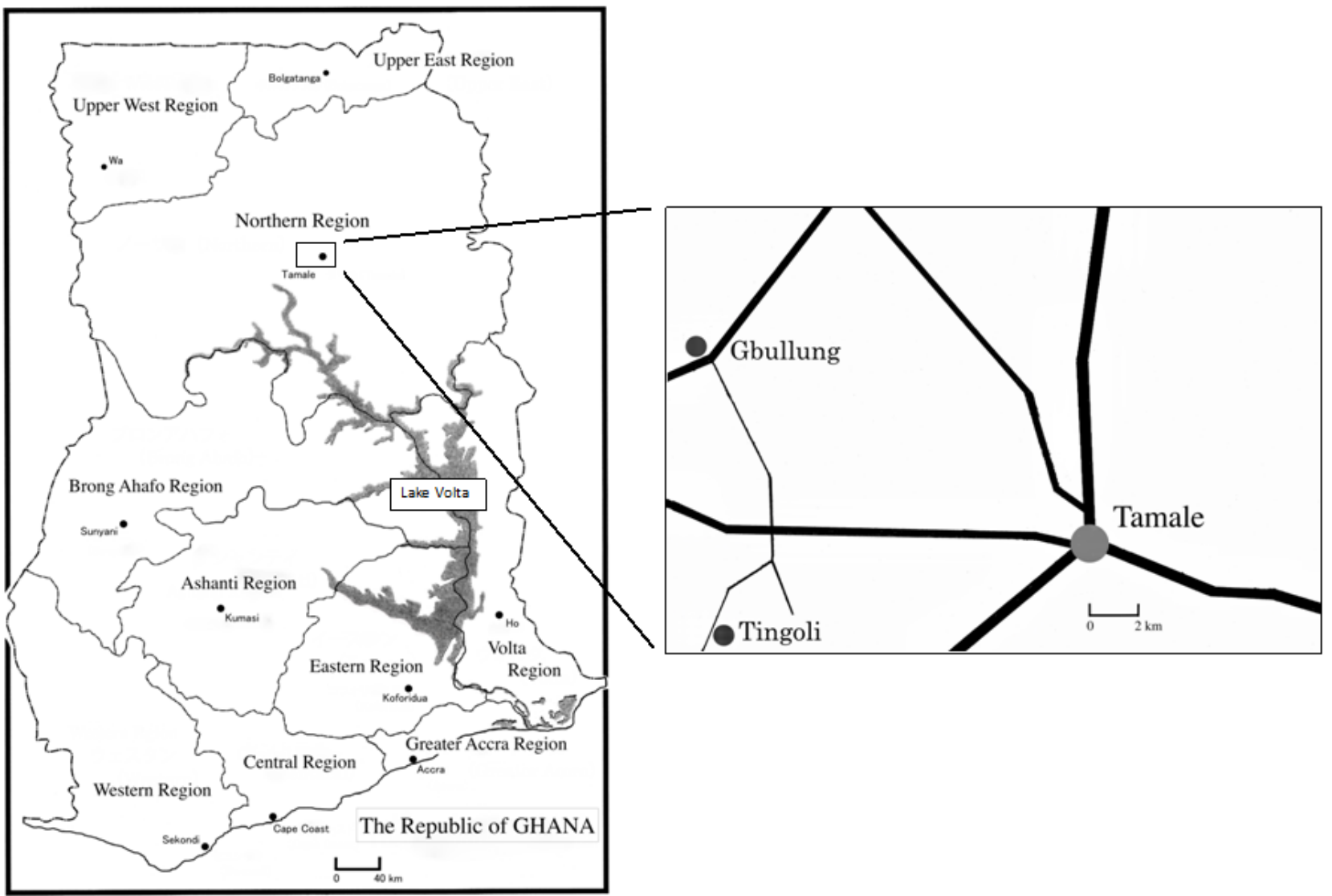

Figure 6. Map of the survey area. (Source: GSS, 2000.)

The village $\mathrm{G}$ has more than 4,000 people living in over 250 compounds. This village is about $10 \mathrm{~km}$ away from the main road connecting Tamale to Tolon, and about 25 $\mathrm{km}$ from Tamale. Though electricity became available in village $G$ a few years ago, many households still uses kerosene lamps for light. Fuel for cooking is firewood and charcoal. Some people use wells for water, but many people use the water of the pond nearby the village. There are few non-agricultural activities in village $G$, and most people are engaged in farming. This village has a clinic. There are also sundries shops and sewing shops. Most people buy seasonings and daily necessities in this village, but many people go to the market in Tamale over the course of a day. This village has a public primary school, an Islamic school, a junior high school and a senior high school; about half of the children in the village go to school every day.

In the survey, we conducted interviews in each of the five compounds of village $T$ and village $G$ at four levels: compound level, farmers' level, field level, and crop level. In addition, the compounds to be surveyed were selected by SARI (Savanna Agricultural Research Institute), Ghana, the cooperating organization of this survey, and opinion leaders of each village, and interviews were conducted with all the farmers living in each compound.

In the compound-level survey, we interviewed the $\mathrm{HHH}$ about family composition, situation of living and livelihoods, land management, and inheritance system. In 
the farmer-level survey, we asked all farmers of the compound about size of land use, sales and consumption of crops, crop inputs and yields, livestock possession, and decision making. In the field-level survey, all the farmers were asked about cultivation methods, sources of labor, and work schedule for each field. For the crop-level survey, all the farmers were asked about specific cultivation techniques and working hours for each crop, as well as yields and sales volumes. The analysis was based on total numbers, average, frequency, percentage, and trend analysis.

\section{Results and Discussion}

\subsection{Changes in Family Size and Number of Farmers in the Surveyed Compound}

Changes in the size of families, the number of farmers, and the proportion of farmers per family in the surveyed compound of village $T$ and village $G$ are presented in Table 2 and Table 3, respectively.

In both villages, the size of families in each compound increases or decreases every year, but the average size of families in the surveyed compound in each village clearly shows a decreasing trend.

In village $\mathrm{T}$, the average family size in compounds decreased from 18.6 to 13.4 during the survey period, but the size of families residing in one compound is relatively large (Table 2). As observed in village $T$, the sizes of families increased and decreased repeatedly in the compounds of $T \_1, T \_2, T \_3$, and $T$ _4 . This change is greatly influenced by the decision to form a branch family by the HHH -- the HHH's brothers or sons become independent and start living with their wives and children. Separating to form branch families is a major factor in the decrease in the size of families of these four compounds. On the other hand, in compounds such as T_5, with few fluctuations in the size of families, no separation of branch families was done during the survey period.

In the village $G$, the average size of families per compound decreased from 16.2 to 10.8 , and the size of the family residing in one compound is smaller than the average value of the village $\mathrm{T}$ (Table 3 ). In the compounds G_2 and G_4, the size of families increased and drastically decreased. The change in the size of families was due to the fact that the families exited for migrant work and moved to other villages for farming (relocation of rural village), not to form branch families. The large decrease in the size of families of the compound $G_{-} 3$ was due to the $\mathrm{HHH}$ leaving the current compound to inherit the role of new $\mathrm{HHH}$ for the original compound, and the wife and young child also accompanied him. In other compounds in the village $G$, family size did not fluctuate so much as in G_1 and G_5.

Table 2. Change in family size and percentage of farmers at each compound in village $T$

\begin{tabular}{|c|c|c|c|c|c|c|c|c|c|c|c|c|c|}
\hline & & 2004 & 2005 & 2006 & 2007 & 2008 & 2009 & 2010 & 2011 & 2012 & 2013 & 2014 & 2015 \\
\hline \multirow{2}{*}{$\mathrm{T}_{-} 1$} & Number of families/compound & 17 & 16 & 15 & 15 & 21 & 21 & 18 & 18 & 17 & 15 & 15 & 15 \\
\hline & Percent of farm/family/compound & 41.2 & 43.8 & 53.3 & 40.0 & 33.3 & 38.1 & 27.8 & 27.8 & 29.4 & 20.0 & 26.7 & 33.3 \\
\hline \multirow{2}{*}{ T_2 } & Number of families/compound & 20 & 22 & 23 & 18 & 18 & 16 & 17 & 15 & 13 & 11 & 11 & 11 \\
\hline & Percent of farm/family/compound & 45.0 & 36.4 & 34.8 & 33.3 & 44.4 & 50.0 & 35.3 & 46.7 & 46.2 & 45.5 & 36.4 & 45.5 \\
\hline \multirow{2}{*}{ T_3 } & Number of families/compound & 17 & 17 & 20 & 11 & 11 & 11 & 11 & 11 & 8 & 8 & 7 & 10 \\
\hline & Percent of farm/family/compound & 41.2 & 58.8 & 40.0 & 54.5 & 54.5 & 45.5 & 54.5 & 54.5 & 50.0 & 37.5 & 57.1 & 40.0 \\
\hline \multirow{2}{*}{ T_4 } & Number of families/compound & 24 & 24 & 24 & 18 & 19 & 23 & 24 & 21 & 20 & 20 & 16 & 16 \\
\hline & Percent of farm/family/compound & 41.7 & 41.7 & 41.7 & 38.9 & 36.8 & 26.1 & 20.8 & 23.8 & 20.0 & 20.0 & 18.8 & 18.8 \\
\hline \multirow{2}{*}{ T_5 } & Number of families/compound & 15 & 17 & 13 & 15 & 14 & 17 & 17 & 15 & 15 & 14 & 14 & 15 \\
\hline & Percent of farm/family/compound & 26.7 & 41.2 & 46.2 & 33.3 & 42.9 & 29.4 & 29.4 & 33.3 & 26.7 & 21.4 & 21.4 & 20.0 \\
\hline \multirow{2}{*}{ T_ave. } & Number of families/compound & 18.6 & 19.2 & 19.0 & 15.4 & 16.6 & 17.6 & 17.4 & 16.0 & 14.6 & 13.6 & 12.6 & 13.4 \\
\hline & Percent of farm/family/compound & 39.1 & 44.4 & 43.2 & 40.0 & 42.4 & 37.8 & 33.6 & 37.2 & 34.4 & 28.9 & 32.1 & 31.5 \\
\hline
\end{tabular}

(Source: Survey data, 2005-2016.).

Table 3. Change in family size and percentage of farmers at each compound in village G

\begin{tabular}{|c|c|c|c|c|c|c|c|c|c|c|c|c|c|}
\hline & & 2004 & 2005 & 2006 & 2007 & 2008 & 2009 & 2010 & 2011 & 2012 & 2013 & 2014 & 2015 \\
\hline \multirow{2}{*}{ G_1 } & Number of families/compound & 11 & 12 & 10 & 10 & 10 & 12 & 12 & 13 & 14 & 14 & 10 & 11 \\
\hline & Percent of farm/family/compound & 36.4 & 41.7 & 50.0 & 40.0 & 20.0 & 25.0 & 25.0 & 30.8 & 21.4 & 21.4 & 20.0 & 18.2 \\
\hline \multirow{2}{*}{ G_2 } & Number of families/compound & 19 & 19 & 21 & 21 & 22 & 17 & 17 & 16 & 15 & 15 & 14 & 15 \\
\hline & Percent of farm/family/compound & 31.6 & 36.8 & 38.1 & 33.3 & 31.8 & 35.3 & 29.4 & 25.0 & 20.0 & 33.3 & 21.4 & 20.0 \\
\hline \multirow{2}{*}{ G_3 } & Number of families/compound & 25 & 22 & 18 & 13 & 16 & 10 & 11 & 10 & 11 & 13 & 11 & 8 \\
\hline & Percent of farm/family/compound & 24.0 & 22.7 & 27.8 & 38.5 & 37.5 & 50.0 & 36.4 & 50.0 & 45.5 & 30.8 & 36.4 & 50.0 \\
\hline \multirow{2}{*}{ G_4 } & Number of families/compound & 15 & 14 & 10 & 10 & 11 & 14 & 14 & 8 & 9 & 9 & 9 & 9 \\
\hline & Percent of farm/family/compound & 46.7 & 28.6 & 40.0 & 30.0 & 27.3 & 28.6 & 28.6 & 37.5 & 22.2 & 33.3 & 33.3 & 22.2 \\
\hline \multirow{2}{*}{ G_5 } & Number of families/compound & 11 & 9 & 9 & 9 & 9 & 9 & 10 & 7 & 7 & 11 & 8 & 11 \\
\hline & Percent of farm/family/compound & 45.5 & 44.4 & 44.4 & 55.6 & 55.6 & 44.4 & 40.0 & 57.1 & 57.1 & 36.4 & 62.5 & 27.3 \\
\hline \multirow{2}{*}{ G_ave. } & Number of families/compound & 16.2 & 15.2 & 13.6 & 12.6 & 13.6 & 12.4 & 12.8 & 10.8 & 11.2 & 12.4 & 10.4 & 10.8 \\
\hline & Percent of farm/family/compound & 36.8 & 34.9 & 40.1 & 39.5 & 34.4 & 36.7 & 31.9 & 40.1 & 33.2 & 31.0 & 34.7 & 27.5 \\
\hline
\end{tabular}

Source: Survey data 2005-2016. 
In the northern part of Ghana, the size of families of the compounds showed an overall decreasing trend because of the reasons already cited plus the migration of men seeking jobs in urban areas. In village $\mathrm{T}$, where population size is small and the village is away from the main road, males generally leave the original compound to form branch families. Village $\mathrm{G}$, located along the main road, has relatively good external access because of its larger population and open regular market, but the village does not have enough land area for crops, so the relocation destination of the farmers is more often other rural villages or urban areas. In other words, men in village $\mathrm{T}$ can stay in the village even if they leave the original compound, but men who leave their compound in village $\mathrm{G}$ will also leave the village.

Because the $\mathrm{HHH}$ determines the land distribution of each compound, the land ownership situation of individual farmers varies. In general, the land is allocated to senior males, and the area given is superior or inferior in relation to that seniority $[14,21]$. However, a few of the HHHs of the compound to be surveyed told us that the land that the village chief has the right to assign is insufficient (since the 1990s in village G; after 2005 around village T), so land is not distributed to a new compound. For this reason, farmers to be separated retain land from the original compound as land of the new compound, so the size of land holding per compound shrinks. The number of farmers who owned and used the land as a whole is decreasing in the compounds surveyed in T village and $G$ village.

The proportion of farmers in each compound family in the village $\mathrm{T}\left(\mathrm{T} \_2\right.$ and $\mathrm{T} \_3$ ) show generally high values the proportion is more than $30 \%$. However, T_1, T_4, and T_5 show less than 30\% after 2009 or 2010, and this proportion is decreasing. Declining farmers' proportion in the compound inevitably increases the dependence for food security on individual farmers. The declining trend in the percentage of farmers in these compounds is due to the fact that many senior males are moving out from the compound.

On the other hand, looking at the proportion of farmers in the village $G$ compounds, we see cases such as $G_{-}$, which showed less than $30 \%$ in 2004 to 2006 but maintained more than 30\% from 2007 to 2015. In G_5, the compound maintained a value of more than $35 \%$ from 2004 to 2014 but showed a value of less than 30\% in 2015. The proportion of farmers in other compounds declined from 2008 to 2010, and in 2015 some compounds had farmer proportions below $20 \%$.

The decreases in the proportion of farmers and the sizes of families in each compound were also greatly involved in maintaining the livelihood of the compound and farm management. Changes in the number of farmers in the compound are smaller than the fluctuation in the size of families because of the separation of branch families and men moving to other rural villages and urban areas. Because adult males from the family generally move out, the proportion of the number of farmers to the size of the family of each compound is generally low. This suggests that the reliance for food security per farmer is increasing in compound management that has maintained livelihoods by farming. Therefore, it is becoming difficult to manage compounds only by farming.

\subsection{Change in the Field Size of Compound}

Looking at the changes in average field size of the compound, we see that the field size decreased in both villages: from 23.28 acres to 9.08 acres in village $\mathrm{T}$, and from 15.35 acres to 8.05 acres in village $G$ during the period 2004-2015 (Table 4 and Table 5). Also, the average field size per farmer decreased from 3.23 acres to 2.39 acres in village $T$. On the other hand, in village $G$, the field size per farmer between 2004 and 2015 did not change significantly -- from 2.79 acres to 2.89 acres. The reason for this might be that in village $\mathrm{T}$ the total field size of the compound is smaller than the decrease in the number of farmers, whereas in village $G$ the decrease in the number of farmers and the total field size of the compound show the same decreasing rate.

The change in the field size of the compound and the change in the average field size per farmer are noticeable in the compound of village T. At T_2, the field size suddenly decreased after the household head passed away, and the field size decreased at the time of implementing the branch family in T_3 and T_4. There are also times when the field size largely decreased in $T \_1$ of village $T$ and $G \_1, G \_3$, and $G_{4} 4$ of village $G$. For example, in $G \_4$, one adult male left in 2005, and another adult male was temporarily absent in other years. So the labor force for farming appeared to be insufficient, and that factor was limiting the size of field. In this way, not only the division of land by the branch family but also the labor shortage within the compound is a major factor in the decrease of field size.

Table 4. Changes in compound field size and average farmer's field size at each compound in village $T$

\begin{tabular}{|c|c|c|c|c|c|c|c|c|c|c|c|c|c|}
\hline & & 2004 & 2005 & 2006 & 2007 & 2008 & 2009 & 2010 & 2011 & 2012 & 2013 & 2014 & 2015 \\
\hline \multirow{2}{*}{$\mathrm{T}_{-1} 1$} & Compound field size & 25.10 & 22.50 & 24.25 & 15.00 & 14.15 & 14.00 & 10.75 & 11.25 & 11.75 & 4.38 & 6.50 & 9.00 \\
\hline & Ave. farmer's field size & 3.59 & 3.21 & 3.03 & 2.50 & 2.02 & 1.75 & 2.15 & 2.25 & 2.35 & 1.46 & 1.63 & 1.80 \\
\hline \multirow{2}{*}{ T_2 } & Compound field size & 27.25 & 26.50 & 16.00 & 17.50 & 17.00 & 27.00 & 16.00 & 12.50 & 19.50 & 13.50 & 11.00 & 9.00 \\
\hline & Ave. farmer's field size & 3.03 & 3.31 & 2.00 & 2.92 & 2.13 & 3.38 & 2.67 & 1.79 & 3.25 & 2.70 & 2.75 & 1.80 \\
\hline \multirow{2}{*}{ T_3 } & Compound field size & 25.30 & 20.35 & 21.00 & 9.35 & 13.25 & 13.50 & 12.00 & 11.00 & 11.00 & 10.00 & 8.75 & 9.25 \\
\hline & Ave. farmer's field size & 3.61 & 2.04 & 2.63 & 1.56 & 2.21 & 2.70 & 2.00 & 1.83 & 2.75 & 3.33 & 2.19 & 2.31 \\
\hline \multirow{2}{*}{$\mathrm{T}_{-4}$} & Compound field size & 25.25 & 18.75 & 21.60 & 13.10 & 15.00 & 15.00 & 12.50 & 14.50 & 13.50 & 14.00 & 7.50 & 8.00 \\
\hline & Ave. farmer's field size & 2.53 & 1.88 & 2.16 & 1.87 & 2.14 & 2.50 & 2.50 & 2.90 & 3.38 & 3.50 & 2.50 & 2.67 \\
\hline \multirow{2}{*}{ T_5 } & Compound field size & 13.50 & 16.50 & 15.50 & 13.50 & 15.25 & 12.75 & 13.25 & 10.00 & 9.75 & 10.00 & 9.00 & 10.13 \\
\hline & Ave. farmer's field size & 3.38 & 2.36 & 2.58 & 2.70 & 2.54 & 2.55 & 2.65 & 2.00 & 2.44 & 3.33 & 3.00 & 3.38 \\
\hline \multirow{2}{*}{ T_ave. } & Compound field size & 23.28 & 20.92 & 19.67 & 13.69 & 14.93 & 16.45 & 12.90 & 11.85 & 13.10 & 10.38 & 8.55 & 9.08 \\
\hline & Ave. farmer's field size & 3.23 & 2.56 & 2.48 & 2.31 & 2.21 & 2.58 & 2.39 & 2.15 & 2.83 & 2.87 & 2.41 & 2.39 \\
\hline
\end{tabular}

Source: Survey data, 2005-2016. 
Table 5. Changes in compound field size and average farmer's field size at each compound in village G

\begin{tabular}{cccccccccccccc}
\hline & & 2004 & 2005 & 2006 & 2007 & 2008 & 2009 & 2010 & 2011 & 2012 & 2013 & 2014 & 2015 \\
\hline \multirow{2}{*}{ G_1 } & Compound field size & 15.00 & 21.00 & 17.00 & 16.00 & 4.00 & 11.00 & 8.00 & 11.00 & 12.75 & 11.00 & 6.00 & 7.00 \\
& Ave. farmer's field size & 3.75 & 4.20 & 3.40 & 4.00 & 2.00 & 3.67 & 2.67 & 2.75 & 4.25 & 3.67 & 3.00 & 3.50 \\
\hline \multirow{2}{*}{ G_2 } & Compound field size & 14.25 & 18.00 & 13.10 & 15.50 & 13.00 & 11.50 & 11.00 & 7.25 & 8.00 & 9.75 & 8.50 & 9.50 \\
& Ave. farmer's field size & 2.38 & 2.57 & 1.64 & 2.21 & 1.86 & 1.92 & 2.20 & 1.81 & 2.67 & 1.95 & 2.83 & 3.17 \\
\hline \multirow{2}{*}{ G_3 } & Compound field size & 18.25 & 21.25 & 20.50 & 14.00 & 17.00 & 10.25 & 11.50 & 10.50 & 12.50 & 7.00 & 7.00 & 10.50 \\
& Ave. farmer's field size & 3.04 & 4.25 & 4.10 & 2.80 & 2.83 & 2.05 & 2.88 & 2.10 & 2.50 & 1.75 & 1.75 & 2.63 \\
\hline \multirow{2}{*}{ G_4 } & Compound field size & 18.75 & 9.00 & 7.00 & 4.00 & 3.00 & 11.00 & 7.25 & 4.25 & 2.50 & 4.75 & 4.30 & 4.50 \\
& Ave. farmer's field size & 2.68 & 2.25 & 1.75 & 1.33 & 1.00 & 2.75 & 1.81 & 1.42 & 1.25 & 1.58 & 1.43 & 2.25 \\
\hline \multirow{2}{*}{ G_5 } & Compound field size & 10.50 & 8.75 & 6.75 & 10.60 & 9.50 & 6.50 & 8.25 & 9.50 & 8.38 & 9.50 & 11.00 & 8.75 \\
& Ave. farmer's field size & 2.10 & 2.19 & 1.69 & 2.12 & 1.90 & 1.63 & 2.06 & 2.38 & 2.09 & 2.38 & 2.20 & 2.92 \\
\hline \multirow{2}{*}{ G_ave. } & Compound field size & 15.35 & 15.60 & 12.87 & 12.02 & 9.30 & 10.05 & 9.20 & 8.50 & 8.83 & 8.40 & 7.36 & 8.05 \\
& Ave. farmer's field size & 2.79 & 3.09 & 2.52 & 2.49 & 1.92 & 2.40 & 2.32 & 2.09 & 2.55 & 2.27 & 2.24 & 2.89 \\
\hline
\end{tabular}

Source: Survey data, 2005-2016.

Furthermore, in village $G$, the average field size per farmer was more than 2 acres during the survey period except in 2008, but the average field size per farmer in village $\mathrm{T}$ has been gradually decreasing. That is, in village $\mathrm{T}$, where the total field size per compound at the beginning of the survey in 2004 was relatively large, the field size decreased because of separation of branch families. As the labor force required for farming decreased, the field size per farmer also declined. In village $G$, the field size of each compound was small since the survey began in 2005, so there was no field to divide for branch families, and these families moved out of the village. Although the farming labor force declined, the field size per farmer has been maintained. Since it is unlikely that the field size of each compound will increase in future, it is necessary to maintain the field size of individual farmers within the compound while adjusting the size of families.

\subsection{Agricultural Scale Reduction and Aging of Farmers}

Among the rural Dagomba, because of the penetration of a market economy, the size of families in the compound decreased, and the size of field per compound also decreased. The reason for these reductions, particularly the size of families, varies with the external and internal conditions of each village. In village $\mathrm{T}$, where the living environment access is underdeveloped -- away from the main road -- the size of families decreased with the formation of branch families, and the field size decreased as land was divided. In village $G$, which is nearby the main road and has good living conditions, the size of families decreased because of family members moving out of the village, and the field size decreased because of labor shortage. Figure 7 and Figure 8 show how the field size of the compounds and the field size per farmer are changing in response to changes in the size of families and the number of farmers in both villages. These figures also show the transition of the average age of farmers in each village.

In village $\mathrm{T}$, the total field size per compound has a strong tendency to shrink (see linear approximation line in Figure 7). The linear approximation line of the average family size and the linear approximation line of the average farmer number also show a decreasing trend. In the case of village $T$, most of the families who leave the compound are branch families. The males heading branch families are often senior farmers in the original compound. Therefore, in village $\mathrm{T}$, the linear approximation line of the average age of farmers in the compounds shows only a moderate upward trend (Figure 7).

In village $G$, the total field size per compound clearlyThe direction of the linear approximation line of the average family size has also a decreasing trend. However, the linear approximation line of the average number of farmers shows a moderate decreasing trend. In village $G$, males who leave the compound are often young males aiming at farming in other villages or migrating tourban areas for better job opportunities. As a result, the linear approximation line of the average age of farmers in compounds of village $\mathrm{G}$ shows an accelerated increasing trend (Figure 8).

Table 6 and Table 7 show the changes in field utilization by farmers in each compound in village $\mathrm{T}$ and village $\mathrm{G}$ during the survey period. The result shows that the reason for exiting are migration, changing jobs, dual job, and the end of a temporary stay in the compound. In the northern part of Ghana, each compound field size decreased with the decrease in the size of families and the number of farmers.

In village $T$, the field size of each farmer is decreasing. In each compound, the field size of farmers responsible for food security of families such as $\mathrm{HHH}$ or HHH's brothers and senior sons is relatively large, and they use the land every year for farming. In this village, since the number of farmers to leave by separation of branch families is many, the field size of the compound as a whole continues to scale down (23.3 acres in 2004 to 9.1 acres in 2015), and the farming scale is shrinking (example: T_1, T_2, T_3, T_4; Table 6). On the other hand, since farmers who leave the original compound by separating to form a branch family are often senior males, the average age of farmers in the compound is rising only moderately, and the aging of the farmers of the compounds surveyed is not progressing (42.6 years old in 2004 to 46.0 years old in 2015). In village $G$, since the young farmers' field size was originally small, even if young farmers leave the compound (example: $G \_2, G \_3$, G_4; Table 7), the size reduction of the field per 
compound is smaller than in village T (15.4 acres in 2004 to 8.1 acres in 2015). However, as a result of young males leaving, the average age of the farmers in the compound is rapidly rising (from 36.2 years old in 2004 to 49.6 years old in 2015), and the aging of farmers is continuing.

Also, farmers leaving to form branch families generally had a relatively high level of responsibility for food security (T_1_2 and 4, T_2_5, T_3_2 and 3, T_4_3) and must be able to control their new compound and manage to farm. Young males (see age of farmer in Table 6) have small fields and do not necessarily farm every year. Because they are not very responsi ble for food security of their families, they are in a relatively free and fluid position, so they can stop farming to change jobs (T_2_7, T_3_4, T_5_5), migrate ( $\mathrm{T} \_4$ _5), and accompany senior family members (T_1_8, T_3_4). There are few cases where females farm in a certain field each year because of fluctuations such as exit due to marriage and temporary stay during pregnancy. Also, because the field size is small, there is not much effect on the compound.

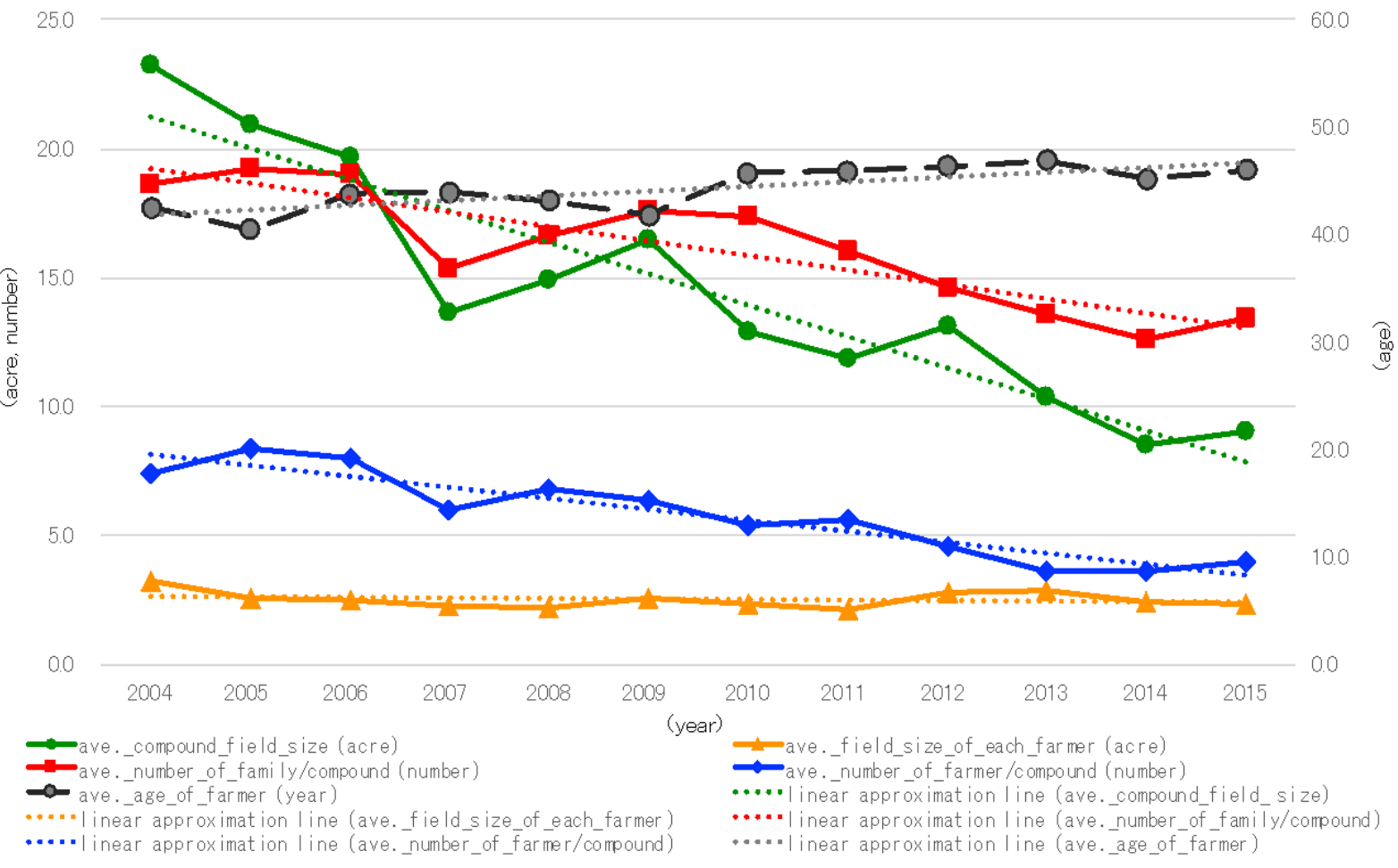

Figure 7. Changes in field size, family size, number of farmers, and average age of farmers in village T (Source: Survey data, 2005-2016.)

$250+600$

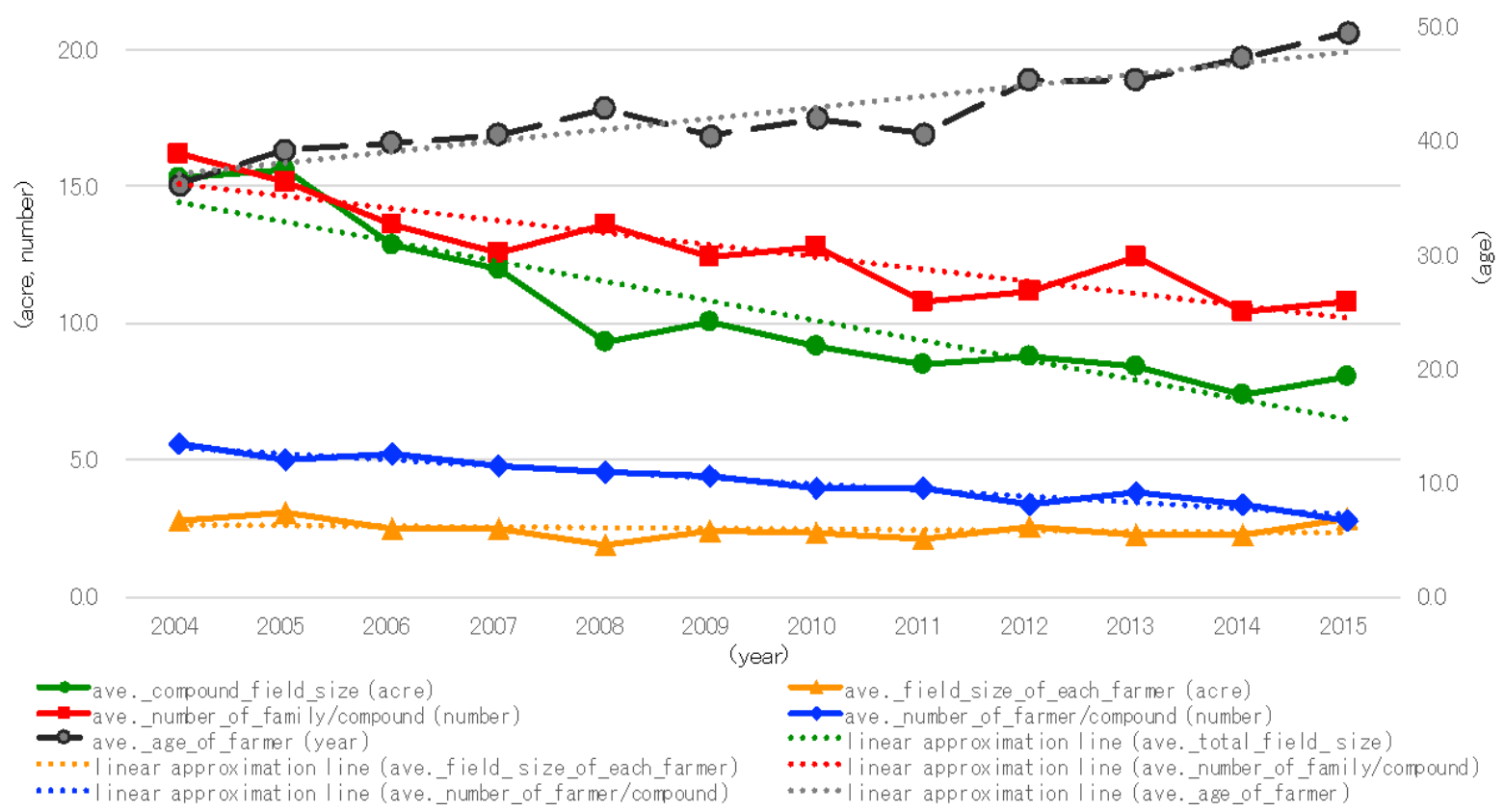

Figure 8. Changes in field size, family size, number of farmers, and average age of farmers in village G (Source: Survey data, 2005-2016.) 
Table 6. Changes of field utilization by farmers in each compound of village $T$

\begin{tabular}{|c|c|c|c|c|c|c|c|c|c|c|c|c|c|c|c|c|}
\hline & Relation & sex & age & 2004 & 2005 & 2006 & 2007 & 2008 & 2009 & 2010 & 2011 & 2012 & 2013 & 2014 & 2015 & Note/comments \\
\hline $\bar{T}$ T_1_1 & hhh & $\mathrm{M}$ & 86 & 7.00 & 8.50 & 10.00 & 5.00 & 5.00 & 5.00 & 4.25 & 4.50 & 4.50 & 3.25 & 3.50 & 4.50 & \\
\hline T_1_2 & son & M & 61 & 3.25 & - & - & - & - & - & - & - & - & - & - & - & Branch family (2005-) \\
\hline T_1_3 & son & $\mathrm{M}$ & 56 & 4.75 & 3.00 & 1.50 & 1.502 & 2.00 & 1.00 & 1.50 & 1.75 & 1.25 & 0.50 & 1.00 & 1.00 & \\
\hline T_1_4 & son & M & 51 & 3.50 & 2.50 & 3.00 & 2.00 & 1.50 & 2.00 & - & - & - & - & - & - & Branch family (2010-) \\
\hline T_1_5 & son & M & 41 & 4.00 & 4.50 & 4.50 & $3.50 \vdots$ & 3.00 & 3.00 & 2.00 & 2.00 & 3.00 & - & 1.50 & 2.00 & \\
\hline T_1_6 & son & M & 36 & 1.50 & 2.50 & 2.25 & 2.00 & 1.50 & 1.50 & 2.00 & 2.50 & 2.50 & 0.63 & 0.50 & 0.50 & \\
\hline T_1_7 & son & M & 23 & - & - & - & - & 0.15 & 0.25 & - & - & - & - & - & - & Other town for school (2013-) \\
\hline T_1_8 & son & M & 21 & - & - & - & - & - & 0.25 & - & - & - & - & - & - & Change of house with T_1_4 (2010-) \\
\hline T_1_9 & wife & F & 81 & - & - & 1.00 & 1.00 & 1.00 & - & - & - & - & - & - & - & No land (2009-) \\
\hline T_1_10 & son's wife & F & 41 & 1.10 & - & - & - & - & - & - & - & - & - & - & - & Change house with husband (2010-) \\
\hline T_1_11 & son's wife & F & 41 & - & 1.00 & 1.00 & - & - & - & - & - & - & - & - & - & Change house with husband (2005-) \\
\hline T_1_12 & daughter & F & 39 & - & 0.50 & 1.00 & - & - & 1.00 & - & - & - & - & - & - & Stay for pregnancy (2005_2006, 2009_2010) \\
\hline T_1_13 & son's wife & F & 53 & - & - & - & - & - & - & 1.00 & 0.50 & 0.50 & - & - & - & Help for husband (2013-) \\
\hline T_1_14 & son's wife & $\mathrm{F}$ & 30 & - & - & - & - & - & - & - & - & - & - & - & 1.00 & Enter the house by marriage (2014-) \\
\hline T_2_1 & former hhh & $\mathrm{M}$ & 82 & 9.00 & 4.00 & 1.50 & - & - & - & - & - & - & - & - & - & Died (2007) \\
\hline T_2_2 & hhh & M & 61 & 4.00 & 3.50 & 3.00 & 4.003 & 3.00 & 2.50 & 5.50 & 3.00 & 3.50 & 2.50 & 5.00 & 2.00 & New HHH (from 2007) \\
\hline T_2_3 & brother & M & 56 & 5.00 & 10.00 & 3.00 & 5.00 & 4.00 & 5.00 & 4.00 & 3.00 & 5.50 & 3.50 & & 3.00 & \\
\hline T_2_4 & cousin & M & 46 & 2.00 & 3.50 & 3.00 & 3.00 & 4.00 & 4.00 & 1.50 & 3.00 & 4.00 & 3.00 & 2.00 & 1.00 & Farming is the side work (tractor operator) \\
\hline T_2_5 & cousin & M & 36 & 3.00 & 2.00 & 3.00 & 3.00 & 2.00 & 4.00 & 2.00 & - & - & - & - & - & Branch family (2012-) \\
\hline T_2_6 & cousin & M & 28 & 1.25 & 1.00 & 0.50 & 1.002 & 2.00 & 2.50 & 2.00 & 1.00 & 1.50 & - & - & - & Move to other village for farming (2013-) \\
\hline T_2_7 & nephew & M & 30 & - & 1.00 & 1.00 & 1.50 & 1.00 & 3.00 & 1.00 & - & - & - & - & - & Move to other town for work (2011-) \\
\hline T_2_8 & nephew & M & 26 & - & - & - & - & - & 4.00 & - & 1.50 & 3.00 & 1.50 & 1.00 & 1.00 & \\
\hline T_2_9 & nephew & M & 19 & - & - & - & - & - & 2.00 & - & 1.00 & 2.00 & 3.00 & 3.00 & 2.00 & \\
\hline T_2_10 & former hhh's wife & F & 81 & 1.00 & 1.50 & 1.00 & - & - & - & - & - & - & - & - & - & Go back to born house (2007-) \\
\hline T_2_11 & wife & F & 56 & 1.00 & - & - & - & - & - & - & - & - & - & - & - & No land (2005-) \\
\hline T_2_12 & brother's wife & F & 46 & 1.00 & - & - & - & 0.50 & - & - & - & - & - & - & - & Pregnancy (2005_2007), no land (2009-) \\
\hline T_2_13 & cousin's wife & F & 41 & - & - & - & - & 0.50 & - & - & - & - & - & - & - & Land only one year (2009) \\
\hline T_3_1 & hhh & M & 59 & 9.00 & 4.00 & 5.00 & 4.50 & 6.50 & 6.00 & 5.50 & 4.00 & 7.00 & 5.50 & 6.00 & 5.75 & \\
\hline T_3_2 & brother & M & 56 & 4.50 & 3.75 & 2.50 & 1.25 & 3.50 & 3.00 & 3.00 & 3.50 & - & - & - & - & Branch family (2012-) \\
\hline T_3_3 & brother & $\mathrm{M}$ & 53 & 6.00 & 5.50 & 4.00 & - & - & - & - & - & - & - & - & - & Branch family (2007-) \\
\hline T_3_4 & brother & M & 50 & 1.50 & 1.50 & 3.75 & - & - & - & - & - & - & - & - & - & Move to other town for work (2007-) \\
\hline T_3_5 & son & M & 26 & - & 1.00 & 1.25 & 0.60 & 1.00 & 1.00 & 2.00 & 2.00 & 3.00 & 2.50 & 1.50 & 2.00 & \\
\hline T_3_6 & son & M & 21 & - & - & - & - & - & - & - & - & - & - & 0.25 & 0.50 & \\
\hline T_3_7 & wife & $\mathrm{F}$ & 56 & 1.10 & 1.10 & 1.00 & 1.00 & 0.75 & 1.50 & 0.50 & 0.50 & 0.50 & 2.00 & 1.00 & 1.00 & \\
\hline T_3_8 & wife & F & 51 & 1.60 & 1.00 & 1.50 & 1.00 & 1.00 & 2.00 & 0.50 & 0.50 & 0.50 & - & - & - & Reduction of field nutrients (2013-) \\
\hline T_3_9 & brother's wife & $\mathrm{F}$ & 47 & - & 0.50 & 1.00 & - & - & - & - & - & - & - & - & - & Change of house with husband (2007-) \\
\hline T_3_10 & brother's wife & $\mathrm{F}$ & 41 & - & 1.00 & - & - & - & - & - & - & - & - & - & - & Change of house with husband (2007-) \\
\hline T_3_11 & brother's wife & F & 42 & 1.60 & 1.00 & - & - & - & - & - & - & - & - & - & - & No land (2006-) \\
\hline T_3_12 & brother's wife & $\mathrm{F}$ & 48 & - & - & 1.00 & 1.00 & 0.50 & - & 0.50 & 0.50 & - & - & - & - & Change of house with husband (2012-) \\
\hline T_4_1 & hhh & M & 68 & 11.50 & 7.00 & 8.00 & 7.00 & 6.00 & 7.00 & 6.00 & 7.00 & 7.00 & 8.00 & 6.00 & 6.00 & \\
\hline T_4_2 & brother & M & 56 & 2.00 & 1.50 & 1.50 & 1.50 & 2.00 & - & - & - & - & - & - & - & Other town for work (2012-) \\
\hline T_4_3 & brother & M & 51 & 2.00 & 1.75 & 1.50 & - & - & - & - & - & - & - & - & - & Branch family (2007-) \\
\hline T_4_4 & brother & M & 41 & 1.50 & 1.50 & 1.50 & 1.00 & 1.75 & 2.00 & 2.00 & 2.50 & 3.00 & 4.00 & - & - & Branch family (2014-) \\
\hline T_4_5 & son & M & 46 & 2.00 & 2.00 & 2.00 & - & - & - & - & 3.00 & 2.50 & 1.00 & 1.00 & 1.00 & Working away from home (2007_2010) \\
\hline T_4_6 & son & M & 31 & 2.00 & 1.25 & 1.50 & - & - & - & - & - & - & - & - & - & Move to other village for farming (2008-) \\
\hline T_4_7 & nephew & M & 27 & 1.50 & 1.00 & 2.25 & 1.50 & 1.25 & 1.50 & 1.50 & 1.00 & 1.00 & 1.00 & 0.50 & 1.00 & \\
\hline T_4_8 & wife & F & 51 & 1.00 & 1.00 & 1.10 & 0.60 & 1.00 & 1.00 & - & - & - & - & - & - & No land (2010-) \\
\hline T_4_9 & brother's wife & F & 51 & 1.25 & 1.25 & 1.00 & 1.00 & 2.00 & 1.00 & 2.00 & 1.00 & - & - & - & - & Change of house with husband (2012-) \\
\hline T_4_10 & wife & $\mathrm{F}$ & 46 & 0.50 & 0.50 & 1.25 & 0.50 & 1.00 & 2.50 & 1.00 & - & - & - & - & - & No land (2012-) \\
\hline T_5_1 & hhh & M & 86 & 5.25 & 7.00 & 6.00 & 5.00 & 6.00 & 4.50 & 5.00 & 4.00 & 3.75 & & & & Stop farming, sickness (2014-) \\
\hline T_5_2 & son & M & 56 & 3.75 & 2.00 & 3.00 & 2.50 & 3.50 & 2.00 & 2.00 & 2.00 & 2.00 & 5.50 & 4.50 & 4.50 & \\
\hline T_5_3 & son & M & 51 & 2.00 & 2.00 & 2.00 & 2.50 & 2.00 & 3.00 & 3.00 & 2.00 & 2.00 & 2.50 & 2.00 & 2.13 & \\
\hline T_5_4 & son & M & 46 & 2.50 & 2.00 & 2.50 & 2.50 & 2.25 & 2.25 & 2.25 & 2.00 & 2.00 & 2.00 & 2.50 & 3.50 & \\
\hline T_5_5 & son & M & 29 & - & 1.50 & 1.00 & - & - & - & - & - & - & - & - & - & Other town for work (2011-) \\
\hline T_5_6 & wife & $\mathrm{F}$ & 63 & - & 1.00 & 1.00 & 1.00 & 1.00 & 1.00 & 1.00 & - & - & - & - & - & No land (2011-) \\
\hline T_5_7 & daughter & $F$ & 48 & - & 1.00 & - & - & - & - & - & - & - & - & - & - & Stay for pregnancy (2005_2006) \\
\hline T_5_8 & son's wife & $F$ & 38 & - & - & - & - & 0.50 & - & - & - & - & - & - & - & Stay for pregnancy (2008_2009) \\
\hline
\end{tabular}

(Source: Survey data, 2005-2016.). 
Table 7. Changes of field utilization by farmers in each compound of village G

\begin{tabular}{|c|c|c|c|c|c|c|c|c|c|c|c|c|c|c|c|c|}
\hline & Relation & $\operatorname{sex}$ & age & 2004 & 2005 & 2006 & 200 & 2008 & 32009 & 2010 & 2011 & 2012 & 2013 & 2014 & 2015 & Note/comments \\
\hline$\overline{G \_1 \_1}$ & hhh & M & 61 & 10.00 & 7.00 & 5.00 & 5.00 & 3.00 & 6.00 & 5.00 & 6.00 & 6.00 & 7.00 & 5.00 & 6.00 & \\
\hline G_1_2 & son & M & 41 & 2.00 & 6.00 & 3.50 & - & - & 4.00 & 2.00 & 3.00 & 5.75 & 3.00 & - & - & Working away (2007_2008, 2014_2015) \\
\hline G_1_3 & son & M & 36 & 1.00 & 3.50 & 3.75 & 5.00 & - & - & - & - & - & - & - & - & Move to village for farming (2008-) \\
\hline G_1_4 & son & M & 36 & - & 3.50 & 3.75 & 5.00 & - & - & - & - & - & - & - & - & Move to village for farming (2008-) \\
\hline G_1_5 & son & M & 25 & - & - & - & - & - & - & - & 1.00 & - & - & - & - & Land only one year (2011) \\
\hline G_1_6 & wife & $\mathrm{F}$ & 51 & 2.00 & 1.00 & 1.00 & 1.00 & 1.00 & 1.00 & 1.00 & 1.00 & 1.00 & 1.00 & 1.00 & 1.00 & \\
\hline$\overline{G \_2 \_1}$ & former hhh & $\mathrm{M}$ & 62 & 7.00 & 6.00 & 3.50 & 5.50 & 3.50 & 3.50 & 5.00 & 2.50 & - & - & - & - & Stop farming (from 2012), Died (2013) \\
\hline G_2_2 & brother & M & 51 & 1.50 & 3.00 & 2.00 & 3.00 & 2.00 & 1.50 & 2.50 & 1.50 & 4.00 & 4.00 & 1.00 & 2.50 & \\
\hline G_2_3 & hhh & M & 43 & 2.00 & 2.50 & 2.00 & - & 3.00 & 3.00 & 1.50 & 2.00 & 3.00 & 3.00 & 2.00 & 5.50 & Farming at another village (2007) \\
\hline G_2_4 & nephew & M & 41 & 2.00 & 2.00 & 1.50 & 2.00 & 2.00 & - & - & - & - & - & - & - & Move to other town for work (from 2009) \\
\hline G_2_5 & nephew & M & 36 & 1.00 & 2.50 & 1.50 & 2.50 & 1.00 & 2.50 & 1.50 & 1.25 & 1.00 & 1.25 & 5.50 & 1.50 & Land only one year (2009) \\
\hline G_2_6 & grand nephew & M & 18 & - & - & - & - & - & 0.50 & - & - & - & - & - & - & \\
\hline G_2_7 & former hhh's wife & $\mathrm{F}$ & 51 & 0.75 & 1.00 & 1.10 & 1.00 & 0.50 & 0.50 & 0.50 & - & - & 1.00 & - & - & Stop farming (2011_2012, 2014-) \\
\hline G_2_8 & former hhh's wife & F & 46 & - & 1.00 & - & - & - & - & - & - & - & - & - & - & Land only one year (2005) \\
\hline G_2_9 & brother's wife & F & 41 & - & - & 1.00 & 1.00 & 1.00 & - & - & - & - & - & - & - & Land from husband (2006_2008) \\
\hline G_2_10 & wife & $\mathrm{F}$ & 39 & - & - & 0.50 & 0.50 & - & - & - & - & - & 0.50 & & & Land from husband (2006_2007, 2013) \\
\hline G_3_1 & former hhh & $\mathrm{M}$ & 81 & 6.75 & 6.00 & 7.00 & 4.00 & 5.50 & - & - & - & - & - & - & - & rn house (from 2009) \\
\hline G_3_2 & hhh & M & 61 & 3.00 & 3.50 & 5.50 & 2.00 & 2.00 & 2.00 & 3.00 & 1.50 & 2.50 & 3.00 & 2.50 & 4.00 & \\
\hline G_3_3 & brother & M & 51 & 2.00 & 3.00 & 2.00 & 3.00 & 3.00 & 2.50 & 3.00 & 2.25 & 4.50 & 1.00 & 1.00 & 2.00 & \\
\hline G_3_4 & brother & M & 36 & 2.00 & 4.75 & 2.00 & 3.00 & 3.50 & 2.75 & 3.00 & 4.00 & 2.50 & 2.00 & 2.00 & 3.50 & \\
\hline G_3_5 & brother & M & 31 & 2.00 & 4.00 & 4.00 & 2.00 & 2.50 & - & - & - & - & - & - & - & Change house with former HHH (from 2009) \\
\hline G_3_6 & son & M & 31 & 2.50 & - & - & - & - & - & - & - & - & - & - & - & Move to other town for work (from 2005) \\
\hline G_3_7 & son & M & 27 & - & - & - & - & 0.50 & 2.00 & 2.50 & 2.50 & 1.50 & 1.00 & 1.50 & - & Died (2015) \\
\hline G_3_8 & son & M & 26 & - & - & - & - & - & 1.00 & - & 0.25 & 1.50 & - & - & 1.00 & Help for HHH (2009, 2013_2014) \\
\hline$\overline{G \_4 \_1}$ & hhh & $\mathrm{M}$ & 76 & 6.00 & 4.00 & 3.00 & 2.50 & 1.50 & 4.50 & 2.75 & 2.75 & 1.50 & 3.50 & 2.30 & 2.50 & \\
\hline G_4_2 & brother & M & 51 & 5.00 & 2.00 & 1.50 & - & 1.00 & 4.50 & 2.00 & - & - & - & - & - & Branch family (from 2011) \\
\hline G_4_3 & brother & M & 41 & 2.00 & - & - & - & - & - & - & - & - & - & - & - & Change of house and job (from 2005) \\
\hline G_4_4 & son & M & 36 & 1.75 & 1.50 & 1.50 & 0.50 & - & 1.00 & 2.00 & 1.00 & - & 0.25 & 1.00 & 2.00 & Temporary absence $(2008,2011)$ \\
\hline G_4_5 & son & M & 26 & - & - & - & - & 0.50 & - & 0.50 & 0.50 & - & - & - & - & Go to school (from 2011) \\
\hline G_4_6 & wife & $\mathrm{F}$ & 51 & 1.00 & 1.50 & 1.00 & 1.00 & - & 1.00 & - & - & 1.00 & 1.00 & 1.00 & - & No land (2008, 2010_2011, 2015) \\
\hline G_4_7 & brother's wife & $\mathrm{F}$ & 37 & 0.50 & - & - & - & - & - & - & - & - & - & - & - & Change of house with husband (from 2005) \\
\hline G_4_8 & sister & $\mathrm{F}$ & 36 & 2.50 & - & - & - & - & - & - & - & - & - & - & - & Change of house for marriage (from 2005) \\
\hline$\overline{G \_5 \_1 ~}$ & hhh & $\mathrm{M}$ & 59 & 4.00 & 3.75 & 2.50 & 5.85 & 4.50 & 4.50 & 4.00 & 4.50 & 2.25 & 3.50 & 3.00 & 3.25 & \\
\hline G_5_2 & brother & M & 46 & 3.25 & 2.25 & 1.75 & 2.75 & 2.50 & - & - & - & - & - & 1.00 & - & Working away from home (2009_2013) \\
\hline G_5_3 & son & M & 32 & 1.00 & 1.75 & 1.50 & 1.25 & 1.25 & 1.25 & 3.00 & 3.50 & 4.75 & 4.75 & 5.50 & 4.50 & \\
\hline G_5_4 & son & M & 28 & - & - & - & 0.25 & 0.25 & 0.50 & 0.25 & 0.50 & 0.38 & 0.25 & 1.00 & - & Help for HHH (2015) \\
\hline G_5_5 & wife & $\mathrm{F}$ & 56 & 1.25 & 1.00 & 1.00 & 0.50 & 1.00 & 0.25 & 1.00 & 1.00 & 1.00 & 1.00 & 0.50 & 1.00 & \\
\hline G_5_6 & daughter & F & 35 & 1.00 & - & - & - & - & - & - & - & - & - & - & - & Change of house for marriage (from 2005) \\
\hline
\end{tabular}

(Source: Survey data, 2005-2016.)

In the case of village $G$, the field size of each farmer tended to decrease, but the field size of the $\mathrm{HHH}$ is relatively large in each compound (G_1, G_4, G_5). However, in some compounds, a new $\mathrm{HHH}$ took over the management of the compound because of the exit or death of the former $\mathrm{HHH}$, but the field size was not directly inherited from the former $\mathrm{HHH}\left(\mathrm{G}_{-} 2, \mathrm{G}_{-} 3\right)$.

In addition, there are cases where farmers who are relatively responsible for family food security of the compound leave to go to another village for farming (G_1_3 and 4), form a branch family for changing jobs(G_4_3), and relocate to urban areas for changing jobs (G_2_4, G_3_6). Furthermore, young males of some compounds in village $G$ temporarily exited the village for farming in other villages (G_2_3) or migrant work to urban areas (G-1-2, G-4-4, G-5-2), so the farming labor force of $\mathrm{HHH}$ and senior farmers of each compound was insufficient. In addition, the females in village $\mathrm{G}$ generally have few fluctuations in field use due to exit or temporary stay.

The survey shows that the compounds in both villages have a decreasing trend in the number of farmers and the field size. However, the factors and scale of reduction are different in each village. If a family of a compound temporarily leaves the original compound or exits because of migration or job change, some other families use that field. Additionally, if a male farmer from the compound leaves, the labor force of the compound as a whole will decrease. So, in each compound, there were not enough farmers who could expand farming by using the fields of leaving farmers/families. In village $T$, because of the separation of branch families in each compound, the original field is divided to provide land for those families, so the average field size shrank. This strongly shows the tendency to reduce the scale of farming. But the average age of farmers increased very little, so aging of farmers is 
not progressing. In each compound of village $G$, the young males left the village, the number of farmers decreased, and the labor force was also short, so the field size of the whole compound decreased.

\section{Conclusion and recommendations}

In recent years, there have been economic disparities between the south and the north areas in Ghana. These economic disparities form a multilayered structure of south and north, urban and rural by rapidly spreading the market economy in the country. The economic disparities appear to be increasing in the rural areas, particularly in the northern area and the urban side in the southern area. Also, because of the effects of economic growth, the position of agriculture as a source of income in rural areas has declined rapidly. Especially in the past few years, since the weight of agriculture as an income source has been rapidly decreasing, even the possibility that de-agrarianization is progressing can be forecasted. Nonetheless, the northern part of Ghana does not produce crops for export and does not have any useful mineral resources. So income from agriculture has assumed an important position.

In response to the movement of such social conditions, farmers in the northern part of Ghana are engaged in farming while each village and each compound responds to changes in external or internal conditions. We analyzed the change of the size of families and number of farmers, the decreasing field size, and clarified three points on the impact of the rapid spread of market economy in northern Ghana.

1) In the northern part of Ghana, the reason for the decrease in the size of families of compounds was males moving out of the original compounds to form branch families or move to other rural villages and urban areas. In the village where external access is poor but there is still a certain extent in the field, farmers stay in the original village in many cases to form branch families. In villages where the size of the population has expanded but there is no margin in thefield, farmers often leave the origin village to move toother rural villages or urban areas.

2) Since the number of farmers in each compound has decreased and the proportion of the number of farmers to the size of families is decreasing, food security dependence per farmer is increasing. For that reason, compound management is becoming harder where farming is the only source of livelihood. As a response, the size of families is controlled by adult males moving to form branch families, moving to other rural villages, and seeking jobs in urban areas.

3) In the northern part of Ghana, the decrease in field size is intense as the number of farmers decreases in the compound. In villages with many branch families, the reduction rate of the field size in the compound is large and the farming scale is shrinking, but the average age of farmers is not progressing. In the originally small-scale farming village where most of the farmers move out of the village, the reduction rate of the field size in the compound is small, but the average age of farmers is increasing because of the exit of the young males.

In the northern part of Ghana, economic liberalization has progressed rapidly since the early 2000s, and even residents of rural villages are needing more cash to obtain necessities for daily living. So, in each compound, some families maintain their livelihoods by doing nonagricultural activities such as migrant work or concurrent work. Meanwhile, problems such as division of land and reduced field size due to formation of branch families in compounds and instability in the farming labor force due to young males' exit from the original village have been shown. And these problems include the possibility of causing other problems, such us farming scale reduction or aging of farmers in compound.

As a practical matter, it would be difficult to maintain a self-sufficient life by producing and consuming the food crops that have been adopted in this area. In other words, changes in the internal condition such as the decrease in the size of families and the number of farmers in the northern part of Ghana and the reduction in field size are caused by changes in external conditions - namely, the need for cash due to the effects of economic liberalization.

Although any changes are dealt with according to the situation, it is unlikely that HHHs who were entrusted with the management of compounds abandoned this life and stopped farming. Also, it is difficult to imagine that the farmers in northern Ghana's unstable and harsh environmental conditions are likely to abandon food crops production and change to cash crop production for sales.

Nonetheless, the impact of the rapid penetration of the market economy in the northern part of Ghana is changing their agriculture and creating new problems of shrinking farming scale and aging farmers. Even if farmers respond flexibly to changes in the external environment, the direction of stable agricultural development in the future is not clear. Therefore, it is important to grasp the present farming system in the northern part of Ghana in detail and to build a development program based on agriculture that has been adopted in the target area rather than simply introduce new production technology and to expand production based on the experience of developed countries.

\section{Acknowledgements}

This study was supported by the Japan Society for the Promotion of Science (JSPS) -- Grant-in-Aid for Scientific Research (C): Grant Number 26450333.

\section{References}

[1] Takane, T. (2002). The Cocoa Farmers of Southern Ghana Incentives, Institutions, and Change in Rural West Africa. Institute of Developing Economies - Japan External Trade Organization, Chiba, Japan.

[2] Nakasone, K., \& Inaizumi, H. (2007). The Change of Compound Farming System on Traditional Rural Village in Northern Ghana. Journal of Rural Community Studies, 105: 41-54.

[3] Nakasone, K. (2013a). Penetration of market economy and the change of agricultural technology in northern Ghana --A case study of Dagomba. Journal of Agricultural Science, 58(2): 71-84. 
[4] Yaro, J. A. (2006). Is deagrarianisation real? A study of livelihood activities in rural northern Ghana. Journal of Modern African Studies, 44(1): 125-156.

[5] GSS. (2014a). Digest of International Merchandise Trade Statistics 2009-2013. Ghana Statistical Service, Accra, Ghana.

[6] GSS. (2011). Revised Gross Domestic Product 2010. Ghana Statistical Service, Ghana.

[7] GSS. (2013). Provisional Gross Domestic Product 2010. Ghana Statistical Service, Ghana.

[8] GSS. (2016). Revised 2015 Annual Gross Domestic Product. Ghana Statistical Service, Accra, Ghana.

[9] ILO HP (2016). ILO Statistics and databases, http://www.ilo.org/global/statistics-and-databases (accessed 08 Sept., 2016).

[10] FAO HP (2016). FAOSTAT, http://www.fao.org/faostat/en/ home (accessed 08 Sept., 2016).

[11] Takane, T. (2007). Structural features of the economy. In Takane et al. (eds.), Agriculture and Forestry in Ghana, pp.1-3. Japan Association for International Collaboration of Agriculture and Forestry, Tokyo, Japan.

[12] Republic of Ghana. (2003). Growth and Poverty Reduction Strategy 2003-2005 -- An Agenda for Growth Prosperity. Republic of Ghana, Ghana.

[13] Republic of Ghana. (2005). Growth and Poverty Reduction Strategy (GPRS II ) (2006-2009). National Development Planning Commission, Ghana.

[14] Nakasone, K. (2013b). Study on the diversification of livelihood activities and change of income acquisition opportunities in rural area of Northern Ghana. Journal of Rural Community Studies, 117: 36-51.

[15] GSS (Ghana Statistical Service). (2000). Ghana Living Standards Survey--Report on The Fourth Round (GLSS4). Ghana Statistical Service, Accra, Ghana.

[16] GSS. (2009). Ghana Living Standards Survey--Report on The Fifth Round (GLSS5). Ghana Statistical Service, Ghana.

[17] GSS. (2014b). Ghana Living Standards Survey--Round 6 (GLSS6). Ghana Statistical Service, Ghana.
[18] Bryceson, F. (1997). De-agrarianisation in Sub-Saharan Africa: Acknowledging the Inevitable. In F. Bryceson, F. and Jamal, V. (eds.), Farewell to Farm De-agrarianisation and Employment in Africa, pp. 3-20. African Studies Centre, Ashgate.

[19] Warner, M., Al-Hassan, R., \& Kydd, J. (1999). A Review of Changes to Farming Systems of Northern Ghana (1957-94). In Roger, B. (ed.), Natural Resource Management in Ghana and Its Socio-economic Context, pp. 85-113. Overseas Development Institute, U.K.

[20] Donhauser, F., Baur, H., \& Langyintuo, A. (1994). Small Holder Agriculture in Western Dagbon; A Farming System in Northern Ghana. Nyankpala Agricultural Research Report No.10. Nyankpala, Ghana.

[21] Nakasone, K. (2002). Study on the Compound Farming of Savanna Rural Area in West Africa (Ph. D. paper). Graduate school of Agriculture, Tokyo University of Agriculture, Tokyo, Japan.

[22] Panin, A. (1988). Hoe and Bullock Farming System in Northern Ghana. Nyankpala Agricultural Research Report No. 1. Nyankpala, Ghana.

[23] Schmidt, G., \& Frey, E. (1988). Crop rotation Effects in Savannah Soil. Nyankpala Agricultural Research Report No. 4. Nyankpala, Ghana.

[24] Runge-Metzger, A., \& Diehl, L. (1993). Farm Household Systems in Northern Ghana; A case study in farming systems oriented research for the development of improved crop production systems. Nyankpala Agricultural Research Report No. 9. Nyankpala, Ghana.

[25] Hesselberg, J., \& Yaro, J. A. (2006). An assessment of the extent and causes of food insecurity in northern Ghana using a livelihood vulnerability framework. GeoJounal, 67: 41-55.

[26] Oppong, C. (1973). Growing Up in Dagbon, Ghana Publishing Corporation, Accra-Tema, Ghana.

[27] Yaro, J. A. (2012). Re-inventing traditional land tenure in the era of land commoditization: some consequences in perurban northern Ghana. Geografiska Annaler: Series B, Human Geography, 94(4): 351-368. 